\title{
Intertekstualitas Jakarta sebagai Ruang Urban dalam Antologi Esai Tiada Ojek Di Paris
}

\author{
Joesana Tjahjani \\ Universitas Indonesia \\ joesana.tjahjani@ui.ac.id
}

How to cite (in APA Style): Tjahjani, J. (2019). Intertekstualitas Jakarta sebagai Ruang Urban dalam Antologi Esai Tiada Ojek di Paris. Jurnal Pendidikan Babasa dan Sastra, 20(1), 16-28. DOI: https://doi.org/10.17509/bs_jpbsp.v20i1.25966

Article History: Received (01 January 2020.); Revised (15 March 2020 ); Accepted (1 April 2020)

Journal homepage: http://ejournal.upi.edu./index.php/BS_JPBSP

\begin{abstract}
Abstrak: Sebagai kota metropolitan, Jakarta tumbuh dengan pesat secara fisik maupun demografis. Dinamika sosial-ekonomi Jakarta juga memperlihatkan perkembangan yang signifikan dari waktu ke waktu. Dalam esai berjudul Tiada Ojek di Paris, Seno Gumira Ajidarma membahas Jakarta sebagai ruang urban yang dipenuhi oleh permasalahan manusia modern. Tulisan ini bertujuan untuk memperlihatkan intertekstualitas yang ada di dalam kumpulan esai tersebut, begitu pula intertekstualitas yang dihasilkan dari penyebutan berbagai teks lain di dalam karya. Pendekatan Strukturalisme Genetik Lucien Goldmann, teori Intertekstualitas Julia Kristeva, dan Konsep Produksi Ruang Henri Lefebvre digunakan sebagai bingkai analisis. Analisis struktur teks memperlihatkan identifikasi Jakarta sebagai ruang urban yang problematik dan dekat dengan realitas keseharian. Hal ini diujarkan oleh narator sekaligus fokalisator dari perspektif akademis, sesuai dengan latar belakang penulis yang merupakan seorang sastrawan sekaligus akademisi. Adapun relasi intertekstual yang terbangun dari rangkaian teks yang ada di dalam Tiada Ojek di Paris merepresentasikan refleksi, kritik, dan wacana dominan yang memproduksi ruang-ruang sosial di ruang urban Jakarta. Sementara itu, intertekstualitas yang dihasilkan dari penyebutan berbagai teks lain di dalam antologi esai mempertegas posisi penulis sebagai sastrawan dan akademisi dalam membangun argumentasi.
\end{abstract}

Kata kunci: Esai; intertekstualitas; produksi ruang; Seno Gumira Ajidarma; strukturalisme

\section{The Intertextuality of Jakarta as Urban Space In The Anthology of Essays Tiada Ojek di Paris}

Abstract: As a metropolitan city, Jakarta is growing rapidly both physically and demographically. Jakarta's socio-economic dynamics also show significant developments over time. In an essay titled Tiada Ojek di Paris, Seno Gumira Ajidarma discusses Jakarta as an urban space that is filled with modern human problems. This paper aims to show the intertextuality that exists in the collection of essays, as well as the intertextuality resulting from the mention of various other texts in the work. Lucien Goldmann's genetic structuralism approach, Julia Kristeva's intertextuality theory, and the concept of the production of space from Henri Lefebvre are used as analytical frameworks. Analysis of the text structure shows the identification of Jakarta as a problematic urban space and close to everyday life reality. This was told by the narrator as well as the focalizer from an academic perspective, according to the background of the author who is a writer as well as an academic. The intertextual relations that are built from a series of texts that exist in Tiada Ojek di Paris represent the reflection, criticism, and dominant discourse that produces social spaces in urban Jakarta. Meanwhile, the intertextuality that results from the mention of various other texts in the anthology of essays confirms the position of the writer as a writer and academic in constructing arguments.

Keywords: Essays; intertextuality; production of space; Seno Gumira Ajidarma; structuralism 


\section{PENDAHULUAN}

Jakarta adalah representasi Indonesia di mata dunia internasional. Sebagai ibukota negara, Jakarta adalah pusat pemerintahan dan perekonomian dari 33 provinsi lainnya. Penduduknya multikultur dan berasal dari hampir semua suku yang ada di Indonesia. Menurut data Badan Pusat Statistik Provinsi DKI Jakarta (BPS, 2018), proyeksi jumlah penduduk DKI Jakarta tahun 2018 mencapai 10.467.629 jiwa; dengan strata sosial-ekonomi yang berbeda-beda. Oleh karena itu, kota metropolitan ini tidak lepas dari permasalahan klasik kota dan manusianya. Banjir dan kemacetan lalu lintas adalah dua masalah besar yang masih sulit dipecahkan oleh pemegang otoritas Jakarta. Sampai hari ini, tingkat kemacetan di Jakarta berada di salah satu peringkat tertinggi di dunia. TomTom Traffic Index (Yudhistira, 2019), mencatat Jakarta berada di peringkat 7 dari 403 kota dunia yang paling macet. Yang menarik, lembaga pengukur tingkat kemacetan di kota-kota dunia itu merilis penurunan level kemacetan Jakarta sebanyak 8 persen, dari 61 persen pada 2017 menjadi 53 persen pada 2018 (Yudhistira, 2019; Firmansyah \& Chairunnisa, 2019).

Permasalahan krusial lain berkaitan dengan manusia Jakarta dengan segala problematika kehidupannya. Beragam persoalan tersebut dipotret dan diungkap oleh Seno Gumira Ajidarma (SGA) dalam antologi esai berjudul Tiada Ojek di Paris (Ajidarma, 2015). Pada bagian Catatan Penulis: Obrolan Urban, SGA mengatakan bahwa buku tersebut adalah kumpulan tulisan dari sejumlah kolom dalam Affair (2004), Kentut Kosmopolitan (2008), dan sejumlah kolom di Djakarta! free-mag hingga tahun 2013 (Ajidarma, 2015). Ada rentang waktu 9 tahun pokok-pokok pikiran SGA yang dimuat dalam buku tersebut. Fokus kumpulan esainya seputar kehidupan warga urban Jakarta yang disebutnya sebagai Homo Jakartensis di dalam ruang-ruang sosial di mana mereka beraktivitas seharihari. Meski demikian, terdapat pula esai yang berkaitan dengan cerita sejarah. Dalam pandangan sosiolog Prancis Henri
Lefebvre, setiap tempat, atau setiap ruang urban, harus menampilkan jenis kontinuitas tertentu yang dihasilkan dari siklus sejarah dan waktu yang menciptakan sejarah tersebut (Nadolny, 2015).

Sebagai pengarang, SGA yang lahir di Boston, Amerika Serikat, 19 Juni 1958, berasal dari keluarga akademisi. Ia adalah seorang cerpenis, esais, wartawan, dan pekerja teater (Ensiklopedia Sastra Indonesia, 2019). Sebagai penulis dari generasi baru sastra Indonesia, banyak karya yang telah dihasilkannya, seperti novel Drupadi, Atas Nama Malam, Wisanggeni-Sang Buronan, Sepotong Senja untuk Pacarku, Biola tak Berdawai, Kalatidha, Kitab Omong Kosong, Dilarang Menyanyi di Kamar Mandi, dan Negeri Senja. Ia juga menulis situasi di Timor Timur dalam trilogi buku Saksi Mata (kumpulan cerpen), Jar, Parfum, dan Insiden (novel), dan Ketika Jurnalisme Dibungkam, Sastra Harus Bicara (kumpulan esai). Karya lain, cerpen Pelajaran Mengarang (cerpen terbaik Kompas 1993), kumpulan cerpen Manusia Kamar, Penembak Misterius, dan Saksi Mata. SGA juga memperoleh banyak penghargaan seperti SEA Write Award, Dinny O'Hearn Prize for Literary Translation for Eyewitness, dan Khatulistiwa Literary Award. Selain sastrawan, SGA juga seorang akademisi yang mengajar di Institut Kesenian Jakarta (IKJ) dan Fakultas Ilmu Pengetahuan Budaya, Universitas Indonesia (FIB UI).

Tulisan ini bertujuan untuk membaca intertekstualitas antara teks-teks yang ada dalam Tiada Ojek di Paris dan penyebutan berbagai teks lain dalam antologi esai tersebut. Strukturalisme genetik Goldmann (1964) digunakan untuk membongkar struktur teks. Teori Intertekstualitas Kristeva (1980) juga dipakai untuk mengungkap korelasi antarteks di dalam antologi serta signifikansi dari penyebutan teks di luar antologi. Sementara itu, Konsep Produksi Ruang Lefebvre (1974, 1991) digunakan untuk menganalisis ruang-ruang sosial di dalam kumpulan esai tersebut. Lefebvre (Elden, 2004, p.148) mengatakan bahwa 
kota dapat dibaca melalui konteksnya. Yang dimaksud dengan konteks adalah apa yang diuraikan di dalam teks (kehidupan sehari-hari, hubungan langsung, dan ketaksadaran urban). Konteks tersembunyi di dalam ruang-ruang yang tidak didiami seperti kehidupan seksual dan keluarga. Dalam menguraikan konteks, apa yang tertera dalam teks, seperti institusi dan ideologi, tidak dapat dinafikan. Bagi kritikus studi budaya perkotaan, investigasi atau kritik terhadap teks budaya bukanlah tujuan akhir dari dirinya sendiri, melainkan titik awal yang penting untuk kritik masyarakat urban (Fraser, 2015, p. 98).

Berkaitan dengan konsep ruang, Lefebvre mengatakan bahwa sesungguhnya tidak ada ruang yang sepenuhnya "ideal" karena ruang itu sendiri secara spasial dalam masyarakat kapitalis modern merupakan arena pertarungan yang tidak akan pernah selesai diperebutkan. Semua pihak yang berkepentingan akan terus berusaha mencari cara untuk mendominasi pemakaian atau pemanfaatan atas suatu ruang dan mereproduksi segala pengetahuan untuk mempertahankan hegemoni mereka atas pemanfaatan ruang tersebut (Pamungkas, 2016). Lefebvre (Schmid, 2008, p. 28) mengatakan bahwa ruang (sosial) adalah produk (sosial); untuk memahami tesis fundamental ini diperlukan perubahan pandangan umum berkaitan dengan ruang yang dibayangkan sebagai realitas material independen yang ada "dalam dirinya (in itself)." Berlawanan dengan hal tersebut, Lefebvre menggunakan konsep produksi ruang sebagai teori untuk memahami ruang sebagai sesuatu yang secara fundamental terikat dengan realitas sosial. Artinya, ruang "dalam dirinya" tidak pernah bisa berfungsi sebagai posisi awal epistemologis. Keberadaan "dalam diri" ruang tidak ada, namun selalu diproduksi. Untuk menjelaskan ruang sebagai produk sosial, Lefebvre (Schmid, 2008, pp. 36-37) mengajukan dimensi triadik dari ruang yang menunjukkan produksi spasial, yaitu: (1) Praktik spasial: konsep ini menunjukkan dimensi material dari aktivitas sosial dan interaksinya. Klasifikasi ruang berfokus pada aspek aktivitas yang simultan. Praktik spasial, dianalogikan dengan dimensi bahasa sintagmatik, menunjukkan sistem yang dihasilkan dari artikulasi dan koneksi antarelemen atau kegiatan. Secara konkret, hal ini terkait dengan jaringan interaksi dan komunikasi yang muncul dalam kehidupan sehari-hari atau dalam proses produksi (produksi dan hubungan pertukaran). (2) Representasi ruang: representasi ruang memberikan gambaran dan mendefinisikan ruang. Analog dengan dimensi bahasa paradigmatik; sebuah representasi spasial dapat digantikan oleh hal lain yang menunjukkan kesamaan tetapi berbeda dalam hal yang lain. Representasi ruang muncul pada tingkat wacana, dan yang diucapkan dalam bentuk verbal seperti deskripsi, definisi, dan terutama teori ruang (bersifat ilmiah). (3) Ruang representasi: dimensi ketiga dari produksi ruang didefinisikan oleh Lefebvre sebagai kebalikan (inversi) dari "representasi ruang". Hal ini menyangkut dimensi simbolis ruang. Ruang representasi tidak merujuk pada ruang itu sendiri tetapi pada sesuatu yang lain: kekuatan ilahi, logo, negara, prinsip maskulin atau feminin, dan sebagainya. Dimensi produksi ruang ini merujuk pada proses signifikansi yang menghubungkan dirinya dengan simbol (material). Simbol ruang dapat diambil dari alam, seperti pohon, formasi topografi yang menonjol atau artefak, bangunan, dan monumen; atau bisa juga merupakan kombinasi keduanya, misalnya sebagai "lanskap."

Selanjutnya Lefebvre (Setiawan, 2017) memandang ketiga konsep produksi ruang tersebut menjadi tiga pengalaman: (1) Perceived space: ruang memiliki aspek perseptif yang dapat ditangkap oleh panca indera. Aspek ini merupakan komponen integral dari setiap praktik sosial, terdiri dari segala sesuatu yang bisa dicerap oleh panca indera; tidak hanya dilihat tapi didengar, dicium, disentuh, dan dirasa. Aspek ini berkaitan dengan materialitas "elemen" yang pada akhirnya menyusun sebuah "ruang". (2) Conceived space: ruang tidak dapat dipersepsi tanpa memahaminya terlebih dahulu di dalam pikiran. 
Merangkai berbagai elemen untuk membentuk suatu "kesatuan yang utuh" yang kemudian disebut sebagai "ruang" merupakan tindakan pikiran dalam memproduksi pengetahuan. (3) Lived space: dimensi ketiga dari produksi ruang adalah pengalaman hidup di dalam ruang. Dimensi ini menunjukkan dunia seperti yang dialami oleh manusia dalam praktek kehidupan sehari-hari mereka. Pada titik ini Lefebvre sangat tegas: bahwa realitas hidup, pengalaman praktis, tidak akan selesai melalui analisis teoritis. Akan selalu terdapat surplus, sisa, atau residu berharga yang tak terjelaskan atau teranalisis, yang terkadang hanya dapat dinyatakan melalui cara-cara artistik.

Beberapa penelitian di tanah air yang menggunakan konsep produksi ruang Lefebvre sebagai pisau analisis banyak terkait dengan permasalahan ruang di wilayah rural dan urban (Sudaryono, 2008; Probowati, 2011; Aminah, 2015; Candra, Nugroho, \& Punia, 2017; Adiprasetio \& Saputra, 2017; Wulandari, 2017; Christian \& Desmiwati, 2018; Pasaribu, Siahaan, \& Tobing, 2018; Nurhadi, Amiruddin, \& Rozalinna, 2019). Namun, penelitian yang berfokus pada intertekstualitas antologi esai Tiada Ojek di Paris melalui pendekatan strukturalisme genetik serta konsep produksi ruang Lefebvre belum banyak dilakukan.

\section{METODE}

Penelitian ini menggunakan metode kualitatif dengan teori Strukturalisme Genetik Lucien Goldmann, Intertekstualitas Julia Kristeva, dan Konsep Produksi Ruang Henri Lefebvre. Pertama-tama, untuk menguraikan struktur teks, dibuat pemetaan topik dari semua esai yang terdapat dalam Tiada Ojek di Paris. Langkah kedua adalah menemukan dan menentukan kehadiran ruang sosial pada semua esai. Selanjutnya, dilakukan pemetaan dan analisis produksi ruang yang menghasilkan praktik spasial, representasi ruang, dan ruang representasi sebagai bahan analisis pada tahap berikutnya. Langkah berikutnya adalah menyelisik kutipan-kutipan argumentatif SGA yang berasal dari pemikiran atau karya-karya orang lain pada setiap teks. Langkah terakhir adalah menganalisis ujaran narator sekaligus fokalisator pada semua esai. Dari pemetaan tersebut, terlihat tema-tema dominan yang akan dilihat signifikansinya seraya mengaitkannya dengan permasalahan ruang dan pengujaran narator-fokalisator. Teori Strukturalisme Goldmann digunakan untuk melihat korelasi antara aspek intrinsik teks, latar belakang penulis, dan konteks sosialbudaya yang melingkupi penulisan karya. Dalam kajian karya filsafat, sastra atau seni yang berhubungan dengan manusia sebagai fakta, kita harus secara cermat mendefinisikannya sesuai signifikansi dari konsep umum "struktur" (Goldmann, 1980). Pemikiran Lefebvre dan khususnya terkait Konsep Produksi Ruang (1974, 1991, Elden, 2004; Schmid, 2008; Fraser, 2015) digunakan untuk mendukung analisis ruang sosial di dalam antologi yang merepresentasikan hubungan dan kondisi sosial budaya masyarakat Jakarta. Terakhir, teori Intertekstualitas Kristeva (1980) digunakan untuk mengungkap signifikansi keberadaan teks-teks lain dalam antologi esai.

\section{HASIL DAN PEMBAHASAN}

\section{Struktur Teks Tiada Ojek di Paris}

Membongkar struktur teks menjadi landasan bagi analisis selanjutnya. Tiada Ojek di Paris merupakan kumpulan esai yang terdiri atas empat puluh empat esai, yang ditulis oleh SGA, pada kurun waktu 2004 sampai 2013. Berikut ini adalah juduljudul esainya (tanpa subjudul), yaitu: (1) Tiga Kota Kontemporer; (2) Manusia Jakarta, Manusia Mobil; (3) Kartu Nama; (4) Dasi Vs. Sendal Jepit; (5) Jakarta, Rembulan, dan Keterasingan; (6) Bajing Melintas di Kabel Listrik; (7) Keberdayaan Gosip; (8) Teater Absurd Permudikan; (9) Terbang (:) (10) Kado Perkawinan; (11) Gresike United, Real Mataram, Tangerang Wolves; (12) Intelektual Starbucks; (13) Kopi; (14) Meski Hanya Rp500,-; (15) Premanisme; (16) Antara New York dan Jakarta; (17) Mengenal Orang Jakarta: 
Jurnal Pendidikan Bahasa dan Sastra, Volume 20, Nomor 1, April 2020, pp. 16 - 28

Mungkinkah?; (18) The Motorcycle People; (19) Bukan-Tontonan; (20) Jakarta Tanpa Indonesia; (21) Uang Dengar (-); (22) Daya Sang Manula; (23) Seruling Bambu di Ruang Jakarta; (24) Mode Kelihatan Pusarnya; (25) Kuburan; (26) Bukan Cengkareng/ Tetap Cengkareng; (27) Penyanyi Dangdut di Tepi Jalan; (28) Dari Jakarta ...; (29) Masihkah Jakarta Berarti Kemenangan; (30) Mahaselingan; (31) Paranoia; (32) Sarapan Berita; (33) Zebra Cross; (34) Listrik Mati; (35) Jakarta
Kosong; (36) Atas Nama Infotainment?; (37) Taman; (38) Mobil: Sebuah Mitos; (39) Jakarta-Bandung, Bandung-Jakarta; (40) Dimensi Ruang: Kisah-Kisah Jakarta; (41) Ojek Sudirman-Thamrin; (42) Jakarta yang Sebenarnya?; (43) Berhala; (44) Jangan (Terlalu) Percaya Media Massa.

Dari empat puluh empat esai tersebut, topik mengenai kehidupan masyarakat Jakarta dapat dirumuskan dalam tabel berikut ini:

Tabel 1. Topik Teks Tiada Ojek di Paris

\begin{tabular}{|c|c|c|c|}
\hline \#Esai & Topik & \#Esai & Topik \\
\hline 1 & Jakarta sebagai Postmodern City & 23 & $\begin{array}{l}\text { Ironi peniup suling jalanan di } \\
\text { tengah kemacetan }\end{array}$ \\
\hline 2 & $\begin{array}{l}\text { Mobil sebagai ruang publik sekaligus } \\
\text { privat }\end{array}$ & 24 & Mitos dunia fashion Homo Jakartensis \\
\hline 3 & $\begin{array}{l}\text { Kartu nama sebagai konstruksi } \\
\text { identitas Homo Jakartensis }\end{array}$ & 25 & $\begin{array}{l}\text { Wacana kuburan dalam konteks } \\
\text { pembangunan }\end{array}$ \\
\hline 4 & Distingsi dalam konstruksi budaya & 26 & $\begin{array}{l}\text { Wacana Cengkareng sebagai } \\
\text { konstruksi sosial }\end{array}$ \\
\hline 5 & Keterasingan/alienasi di Jakarta & 27 & $\begin{array}{l}\text { Musik sebagai representasi ekspresi } \\
\text { penderitaan kelas bawah }\end{array}$ \\
\hline 6 & $\begin{array}{l}\text { Makna Jakarta sebagai hutan urban } \\
\text { bagi Homo Jakartensis }\end{array}$ & 28 & $\begin{array}{l}\text { Beragam penanda identitas Homo } \\
\text { Jakartensis }\end{array}$ \\
\hline 7 & Produksi makna gosip & 29 & $\begin{array}{l}\text { Sinisme makna Jakarta yang berarti } \\
\text { kemenangan }\end{array}$ \\
\hline 8 & $\begin{array}{l}\text { Mudik sebagai identitas Homo } \\
\text { Jakartensis }\end{array}$ & 30 & $\begin{array}{l}\text { Sensasi fisikal-spiritual sebagai } \\
\text { selingan Homo Jakartensis }\end{array}$ \\
\hline 9 & Pesawat sebagai cultural economy & 31 & Ketakutan Homo Jakartensis \\
\hline 10 & $\begin{array}{l}\text { Politik pemberian bagi Homo } \\
\text { Jakartensis }\end{array}$ & 32 & Ritus berita pagi Homo Jakartensis \\
\hline 11 & Representasi-Reartikulasi identitas & 33 & $\begin{array}{l}\text { Zebra Cross sebagai identitas jalanan } \\
\text { Homo Jakartensis }\end{array}$ \\
\hline 12 & $\begin{array}{l}\text { Kafe-UI sebagai negosiasi penanda } \\
\text { gaya hidup }\end{array}$ & 34 & $\begin{array}{l}\text { Penanda sumber energi sebagai } \\
\text { kiamat kecil }\end{array}$ \\
\hline 13 & $\begin{array}{l}\text { Kopi sebagai komodifikasi budaya } \\
\text { Homo Jakartensis }\end{array}$ & 35 & $\begin{array}{l}\text { Identitas terkehendaki Homo } \\
\text { Jakartensis }\end{array}$ \\
\hline 14 & $\begin{array}{l}\text { Pupusnya kejujuran pada masyarakat } \\
\text { kecil }\end{array}$ & 36 & $\begin{array}{l}\text { Jurnalisme sebagai pembongkaran } \\
\text { privacy }\end{array}$ \\
\hline 15 & Preman sebagai koruptor berdasi & 37 & Taman sebagai penanda identitas \\
\hline 16 & Referensi kota dunia untuk Jakarta & 38 & $\begin{array}{l}\text { Mitos dan wacana kritik ideologi } \\
\text { mobil }\end{array}$ \\
\hline 17 & Keasingan interaksi humanis & 39 & $\begin{array}{l}\text { Bandung sebagai ruang publik wajib } \\
\text { kunjung }\end{array}$ \\
\hline 18 & $\begin{array}{l}\text { Motorycle People: Ideologi jalanan } \\
\text { Homo Jakartensis }\end{array}$ & 40 & $\begin{array}{l}\text { Dimensi ruang Jakarta sebagai } \\
\text { keluasan semu }\end{array}$ \\
\hline 19 & Kritik terhadap kekerasan di jalanan & 41 & $\begin{array}{l}\text { Ojek sebagai representasi } \\
\text { perjuangan kelas Homo Jakartensis }\end{array}$ \\
\hline
\end{tabular}


20 Egoisme Jakarta sebagai ibukota

21 Ideologi dana taktis Homo Jakartensis

22 Produktivitas mental Manula

Semua topik yang dirumuskan dari 44 esai ternyata berfokus pada dua hal, yakni yang berhubungan dengan penggambaran kota Jakarta dan uraian yang merujuk pada masyarakat Jakarta. Ditemukan 12 esai yang menggambarkan kota Jakarta, yaitu nomor 1, 5, 6, 16, 20, $25,26,29,34,37,40,42$. Sementara itu, 32 esai lainnya, nomor $2,3,4,7-15,17-19$, $21-24,27,28,30-33,35,36,38,39,41,43$, dan 44; menarasikan uraian tentang perilaku dan gaya hidup masyarakat Jakarta. Dalam antologi, SGA sering menyebut masyarakat Jakarta sebagai Homo Jakartensis. Kedua belas esai yang berkaitan dengan kota Jakarta menghadirkan ibu kota Indonesia itu sebagai kota metropolitan, dengan berbagai aspek pertumbuhan terutama pembangunan di beberapa wilayahnya. Pembangunan kota Jakarta disebutkan memiliki referensi pada kota-kota besar di dunia. Klasifikasi dari kedua belas esai juga merefleksikan pertentangan kelas. Sementara itu, kelompok esai yang berfokus pada manusia Jakarta atau Homo Jakartensis mendeskripsikan sikap dan perilaku masyarakat Jakarta yang berusaha mengikuti peradaban modern di satu sisi dan yang gagap mengikuti arus modernisasi.

Sesuai teori Goldmann tentang Strukturalisme Genetik (1964), semua topik dalam esai Tiada Ojek di Paris, yang membentuk struktur teks, mencerminkan korelasi antara teks, gagasan pengarang, dan konteks sosial yang melingkupi permasalahan kota Jakarta. Modernisasi Jakarta sebagai ruang sosial memproduksi diferensiasi kelas di antara masyarakat Jakarta. Secara eksplisit, struktur teks
Keberagaman dan penyeragaman

Jakarta

TV Kabel sebagai penanda

43

globalisasi dan kosmopolitanisme

bagi Homo Jakartensis

Kuasa media dalam membangun makna ideologis-kapitalistik memperlihatkan hubungan yang tidak selaras antara kota dan masyarakatnya, sedangkan secara implisit, struktur teks dapat dibaca sebagai kritik SGA terhadap dampak pembangunan Jakarta sebagai ruang urban yang modern dan dinamis.

Hal lain yang dapat ditemukan sebagai intertekstualitas di antara semua esai dalam Tiada Ojek di Paris terletak pada tataran pengujaran. SGA ternyata berperan sebagai narator-fokalisator pada 32 dari 44 esai. Hal ini ditandai dengan penggunaan pronomina 'Saya' dalam esai-esai yang dimaksud. Adapun, dalam 12 esai lainnya, narator 'Saya' hadir secara implisit melalui penggunaan pronomina 'Kita'. Signifikansi dari temuan tentang aspek pengujaran adalah pemosisian SGA sebagai penulis esai. Dalam konteks ini, dapat dikatakan bahwa esai-esai dalam antologi itu merupakan pengamatan dan pengalaman langsung dari sang penulis esai. Narasi yang dihadirkan merupakan hasil refleksi dan kritik tentang wacana dominan Jakarta sebagai ruang urban.

\section{Intertekstualitas dalam Tiada Ojek di Paris}

Bagian ini memperlihatkan korelasi antaresai yang ada dalam antologi Tiada Ojek di Paris. Setelah dibaca dengan saksama, antologi ini menunjukkan kehadiran latar ruang hampir di semua esai, atau 34 dari 44 esai. Hanya 10 dari 44 esai yang tidak memperlihatkan latar ruang secara fisik di dalam teks. Setelah ditemukan kehadiran ruang, analisis dikembangkan dengan mengklasifikasikan produksi ruang yang tersebar di seluruh teks, seperti terlihat dalam tabel berikut ini. 
Jurnal Pendidikan Bahasa dan Sastra, Volume 20, Nomor 1, April 2020, pp. 16 - 28

Tabel 2. Produksi Ruang Sosial dalam Teks Tiada Ojek di Paris

\begin{tabular}{|c|c|c|c|c|c|}
\hline $\begin{array}{l}\text { Ruang } \\
\text { Sosial }\end{array}$ & $\begin{array}{l}\text { Nomor } \\
\text { Esai }\end{array}$ & $\begin{array}{l}\text { Jumlah } \\
\text { Esai }\end{array}$ & $\begin{array}{c}\text { Praktik Spasial } \\
\text { (Perceived } \\
\text { Space) }\end{array}$ & $\begin{array}{l}\text { Representasi } \\
\text { Ruang } \\
\text { (Conceived } \\
\text { Space) }\end{array}$ & $\begin{array}{c}\text { Ruang } \\
\text { Representasi } \\
\text { (Lived Space) }\end{array}$ \\
\hline Kota & $\begin{array}{l}1,5,6 \\
8,16\end{array}$ & 5 & $\begin{array}{l}\text { 1. Kaum miskin } \\
\text { kota yang } \\
\text { tersisih oleh } \\
\text { pembangunan } \\
\text { fisik kota. } \\
\text { 2. Budaya mudik } \\
\text { tahunan warga } \\
\text { kota } \\
\text { metropolis. }\end{array}$ & $\begin{array}{l}\text { Pusat } \\
\text { pemerintahan, } \\
\text { pemukiman, } \\
\text { ekonomi, } \\
\text { politik, dan } \\
\text { sosial budaya. }\end{array}$ & $\begin{array}{l}\text { Modern- } \\
\text { tradisional yang } \\
\text { menghasilkan } \\
\text { keterasingan }\end{array}$ \\
\hline Mobil & 2,38 & 2 & $\begin{array}{l}\text { Mitos mobil dan } \\
\text { budaya warga } \\
\text { dalam kemacetan } \\
\text { Jakarta. }\end{array}$ & $\begin{array}{l}\text { Alat transportasi } \\
\text { kelas menengah- } \\
\text { atas. }\end{array}$ & $\begin{array}{l}\text { Penanda identitas } \\
\text { kelas dan 'Dunia } \\
\text { Ketiga'. }\end{array}$ \\
\hline Pesawat & 9 & 1 & $\begin{array}{l}\text { Penumpang } \\
\text { semakin banyak } \\
\text { karena harga tiket } \\
\text { murah. }\end{array}$ & $\begin{array}{l}\text { Alat transportasi } \\
\text { udara yang elitis. }\end{array}$ & $\begin{array}{l}\text { Dekonstruksi } \\
\text { prestise }\end{array}$ \\
\hline $\begin{array}{l}\text { Pesta } \\
\text { perkawinan }\end{array}$ & 10 & 1 & $\begin{array}{l}\text { Penyesuaian } \\
\text { kado perkawinan } \\
\text { sesuai kelas sosial } \\
\text { pengundang. }\end{array}$ & $\begin{array}{l}\text { Peresmian } \\
\text { ikatan } \\
\text { perkawinan } \\
\text { secara norma } \\
\text { agama, hukum, } \\
\text { dan sosial sesuai } \\
\text { tradisi suku } \\
\text { bangsa, agama, } \\
\text { dan kelas sosial. }\end{array}$ & $\begin{array}{l}\text { Wacana } \\
\text { transaksional }\end{array}$ \\
\hline Kafe & 12,13 & 2 & $\begin{array}{l}\text { Pembukaan kafe } \\
\text { Starbucks di UI, } \\
\text { kampus } \\
\text { perjuangan } \\
\text { seiring dengan } \\
\text { berkembangnya } \\
\text { budaya 'ngopi'. }\end{array}$ & $\begin{array}{l}\text { Tempat minum } \\
\text { kopi kelas } \\
\text { menengah-atas } \\
\text { yang nyaman. }\end{array}$ & Mitos gaya hidup \\
\hline $\begin{array}{l}\text { Gerbang } \\
\text { tol }\end{array}$ & 14 & 1 & $\begin{array}{l}\text { Uang kembalian } \\
\text { dari penjaga tol } \\
\text { yang kurang Rp } \\
500,-\end{array}$ & $\begin{array}{l}\text { Tempat } \\
\text { transaksi antara } \\
\text { penjaga dan } \\
\text { pengguna jasa } \\
\text { tol. }\end{array}$ & Harga kejujuran \\
\hline Jalanan & $\begin{array}{l}15,18 \\
19,23 \\
27,33 \\
41\end{array}$ & 7 & $\begin{array}{l}\text { Perilaku dan } \\
\text { budaya warga di } \\
\text { jalan serta adanya } \\
\text { warga kelas } \\
\text { bawah yang } \\
\text { mencari } \\
\text { penghidupan di } \\
\text { jalanan Jakarta. }\end{array}$ & $\begin{array}{l}\text { Prasarana } \\
\text { transportasi } \\
\text { darat dan sarana } \\
\text { mobilisasi } \\
\text { manusia. }\end{array}$ & $\begin{array}{l}\text { Arena perjuangan } \\
\text { kelas. }\end{array}$ \\
\hline
\end{tabular}




\begin{tabular}{|c|c|c|c|c|c|}
\hline Kampus & 24 & 1 & $\begin{array}{l}\text { Mode berbusana } \\
\text { mahasiswa/i } \\
\text { yang berjeans } \\
\text { robek dan } \\
\text { terlihat paha, } \\
\text { serta baju } \\
\text { kependekan } \\
\text { sehingga } \\
\text { kelihatan } \\
\text { pusarnya. }\end{array}$ & $\begin{array}{l}\text { Pusat } \\
\text { intelektualitas } \\
\text { dan menjadi } \\
\text { tempat } \\
\text { menuntut ilmu. }\end{array}$ & $\begin{array}{l}\text { Penanda identitas } \\
\text { mahasiswa } \\
\text { sebagai resistensi } \\
\text { kelas dominan. }\end{array}$ \\
\hline Kuburan & 25 & 1 & $\begin{array}{l}\text { Orang berziarah } \\
\text { kubur untuk } \\
\text { menghormati } \\
\text { orang yang telah } \\
\text { meninggal, } \\
\text { karena kuburan } \\
\text { adalah bagian } \\
\text { dari kehidupan. }\end{array}$ & $\begin{array}{l}\text { Tempat } \\
\text { menguburkan } \\
\text { orang yang } \\
\text { sudah } \\
\text { meninggal. }\end{array}$ & $\begin{array}{l}\text { Wacana ruang } \\
\text { dan waktu. }\end{array}$ \\
\hline Jakarta & $\begin{array}{l}17,20 \\
28,29 \\
30,31 \\
34,35 \\
40,42\end{array}$ & 10 & $\begin{array}{l}\text { Perilaku sehari- } \\
\text { hari dan budaya } \\
\text { warga serta } \\
\text { pandangan orang } \\
\text { daerah terhadap } \\
\text { Jakarta. }\end{array}$ & $\begin{array}{l}\text { Ibukota negara } \\
\text { yang metropolis } \\
\text { serta barometer } \\
\text { nasional dalam } \\
\text { bidang politik, } \\
\text { ekonomi, sosial, } \\
\text { dan budaya. }\end{array}$ & Wacana identitas \\
\hline Bandara & 26 & 1 & $\begin{array}{l}\text { Peran warga } \\
\text { penggarap } \\
\text { perkebunan } \\
\text { Cengkareng di } \\
\text { era kolonial } \\
\text { hingga berubah } \\
\text { menjadi bandara } \\
\text { internasional di } \\
\text { masa kini dengan } \\
\text { segala aktivitas } \\
\text { penumpang. }\end{array}$ & $\begin{array}{l}\text { Fasilitas bagi } \\
\text { penumpang } \\
\text { untuk } \\
\text { brepergian naik } \\
\text { pesawat terbang. }\end{array}$ & $\begin{array}{l}\text { Historisitas ruang } \\
\text { dan waktu. }\end{array}$ \\
\hline Taman & 37 & 1 & $\begin{array}{l}\text { Taman kota } \\
\text { menjadi tempat } \\
\text { gelandangan, } \\
\text { anak jalanan, dan } \\
\text { PSK, sebaliknya } \\
\text { taman di } \\
\text { pemukiman } \\
\text { mewah bersih } \\
\text { dan ada kolam } \\
\text { yang justru } \\
\text { menjadi tempat } \\
\text { anak-anak } \\
\text { kampung } \\
\text { bermain. }\end{array}$ & $\begin{array}{l}\text { Kebun yang } \\
\text { ditanami bunga- } \\
\text { bunga sebagai } \\
\text { ruang terbuka } \\
\text { hijau. }\end{array}$ & Diferensiasi kelas \\
\hline Bandung & 39 & 1 & $\begin{array}{l}\text { Kebiasaan warga } \\
\text { Jakarta ke }\end{array}$ & $\begin{array}{l}\text { Paris van Java, } \\
\text { kota yang }\end{array}$ & Wacana selingan \\
\hline
\end{tabular}




\begin{tabular}{cll}
\hline & $\begin{array}{l}\text { Bandung ketika } \\
\text { weekend karena } \\
\text { waktu perjalanan } \\
\text { 'hanya' 2 jam. }\end{array}$ & $\begin{array}{l}\text { menjadi kiblat } \\
\text { mode seperi di } \\
\text { Paris, Prancis. }\end{array}$ \\
\hline Jumlah & $\mathbf{3 4}$ & \\
\hline
\end{tabular}

\begin{abstract}
Berdasarkan tabel pengelompokan produksi ruang di dalam teks, terlihat bahwa terdapat hubungan antara masyarakat dengan sistem ruangnya. Terdapat 34 esai yang mempunyai konteks ruang sebagai bahan analisis, yakni nomor 1, 2, 5, 6, 8-10, 12-20, 23-31, 33-35, 37-42. Sementara itu, 10 esai tidak menghadirkan ruang fisik, yakni nomor 3, 4, 7, 11, 21, 22, 32, 36, 43, 44. Dengan kalimat berbeda, terdapat 34 ruang sosial dalam TOdP. Tabel 2 memperlihatkan bahwa 'Jakarta' adalah ruang sosial yang paling dominan (10 esai), disusul ruang 'jalanan' (7 esai), dan ruang 'kota' (5 esai). Lefebvre (1974) menguraikan bahwa ruang yang diproduksi berfungsi sebagai instrumen berpikir dan bertindak. Ruang sosial menjadi sarana produksi, kendali, sekaligus sarana dominasi dan kekuatan. Demikianlah, ruang sekaligus mengatur dan menjadi hubungan sosial bagi individu-individu yang hidup di dalamnya. Artinya, ruang 'Jakarta, Jalanan, dan Kota' merupakan tiga ruang paling dominan yang memproduksi relasi sosial bagi individu-individu dalam berpikir dan bertindak dalam aktivitas sehari-hari kaum urban seperti pekerjaan, kehidupan pribadi, dan waktu luang di dalam teks.
\end{abstract}

Praktik spasial dalam tabel merupakan narasi SGA yang muncul di setiap esai. Tidak mudah untuk menentukan praktik spasial dalam sebuah ruang sosial yang muncul lebih dari satu esai, karena topik dan narasi ruang yang disajikan pengarang sangat bervariasi. Secara sintagmatik, interaksi yang terbaca dari praktik spasial tersebut terjadi di berbagai tempat seperti di rumah, jalanan, bandara, pesta perkawinan, gerbang tol, dan lain-lain. Pembacaan mendalam dan pengklasifikasian latar peristiwa praktik spasial pada 34 esai tersebut menghasilkan 13 representasi ruang yang dapat memberikan gambaran sekaligus mendefinisikan ruang-ruang tertentu. Dalam satu esai, mungkin saja terdapat lebih dari satu tempat yang menjadi latar peristiwa. Namun, setelah dibaca dengan cermat, komponen makna yang muncul pada esai tersebut merujuk pada satu tempat yang menjadi representasi ruang tertentu. Secara paradigmatik, representasi ruang tersebut dapat menunjukkan kesamaan dan perbedaan yang dapat dianalisis lebih lanjut. Oleh karena itu, representasi ruang 'Kota', 'Mobil', 'Pesawat', dan lain-lain, diinterpretasikan sebagai ruang sosial yang diproduksi dan menjadi representasi gagasan, wacana, dan narasi persoalan urban di dalam teks. Representasi ruang ini juga berfungsi sebagai dasar dan kerangka referensi dalam menganalisis dan memaknai produksi wacana terkait ruang representasi pada tataran selanjutnya.

Produksi wacana tersebut dirumuskan berdasarkan pemaknaan kritis yang ditemukan pada setiap esai. Peristiwa atau narasi yang diujarkan SGA menghadirkan ruang sosial dan pemaknaan baru melalui sistem tanda, kode, dan bahasa (Lefebvre, 1991, p. 33). Signifikansi dari representasi ruang 'Kota' dimaknai sebagai ruang representasi tentang dikotomi kehidupan modern-tradisional yang menghasilkan keterasingan manusia. Representasi ruang 'Mobil' bermakna sebagai ruang representasi penanda identitas kelas dan 'Dunia Ketiga' bagi warga Jakarta; 'Pesawat' bermakna dekonstruksi prestise; 'Pesta perkawinan' bermakna wacana transaksional; 'Kafe' bermakna mitos gaya hidup; 'Gerbang tol' bermakna harga kejujuran; 'Jalanan' bermakna arena perjuangan kelas; 'Kampus' bermakna penanda identitas mahasiswa sebagai resistensi kelas dominan; 'Kuburan' bermakna wacana ruang dan waktu; 'Jakarta' bermakna wacana identitas; 'Bandara' bermakna 
historisitas ruang; 'Taman' bermakna diferensiasi kelas; dan 'Bandung' bermakna sebagai wacana selingan. Dengan kalimat berbeda, 13 ruang representasi dalam teks menjadi wahana dalam menyampaikan makna-makna sebagai simbol ruang sosial baru yang dapat mengungkapkan norma, nilai, dan juga pengalaman sosial.

Dari tiga belas wacana ruang sosial dalam teks antologi, terlihat tiga wacana dominan yang muncul, yakni wacana identitas yang diproduksi dan dikonstruksi melalui representasi ruang 'Jakarta', wacana arena perjuangan kelas melalui jalanan, dan wacana dikotomi modern-tradisional yang menghasilkan keterasingan melalui kota sebagai representasi ruang. Hal ini dapat diartikan bahwa kumpulan esai SGA terfokus pada persoalan sosial yakni identitas Jakarta, kerasnya perjuangan kelas di jalanan, serta keterasingan kota akibat dikotomi modern-tradisional. Temuan ini mendukung realitas Jakarta yang berkutat dengan persoalan identitas kota metropolitan, masalah sosial di jalanan, dan gegar budaya menerima 'modernitas' yang berlangsung cepat dan masif.

\section{Intertekstualitas Tiada Ojek di Paris dengan Teks Lain}

Seperti pada bagian sebelumnya, analisis pada bagian ini diawali dengan memperhatikan secara cermat penyebutan beragam teks dalam antologi. Teks yang dimaksud dalam hal ini dapat berupa judul karya, baik teori/konsep, karya seni dan sastra, maupun teks yang merujuk pada tokoh tertentu, peristiwa sejarah, dan media massa. Setelah itu, disusun tabel yang memperlihatkan frekuensi kemunculan masing-masing teks sesuai dengan kategori yang dimaksud, seperti terlihat dalam tabel berikut:

Tabel 3. Intertekstualitas Teks Tiada Ojek di Paris

\begin{tabular}{|c|c|c|c|}
\hline No. & Kategori Teks & Nomor Esai & Jumlah \\
\hline 1 & Teori/Konsep & $\begin{array}{l}1,4,7,8,10,11,12,13,16,18,19,21,22,23,24,26 \\
35,43\end{array}$ & 18 \\
\hline 2 & Nama Tokoh & $3,6,22,29$ & 4 \\
\hline 3 & $\begin{array}{l}\text { Karya/Seni } \\
\text { Sastra }\end{array}$ & $5,12,13,17,19,20,22,26,29,31,37,38$ & 12 \\
\hline 4 & Karya/Seni Film & $15,34,42$ & 3 \\
\hline 5 & $\begin{array}{l}\text { Karya/Seni } \\
\text { Musik }\end{array}$ & 20,42 & 2 \\
\hline 6 & Peristiwa Sejarah & $12,18,19,22,25,44$ & 6 \\
\hline 7 & Media Massa & $13,22,32,36,43$ & 5 \\
\hline 8 & Forum Ilmiah & 13 & 1 \\
\hline \multirow[t]{2}{*}{9} & Poster & 41 & 1 \\
\hline & & Jumlah & 52 \\
\hline
\end{tabular}

Seperti telah dikemukakan, berbagai teks yang disebut dalam antologi dikelompokkan menurut kategori teks. Didapat sembilan kategori teks seperti tertera dalam tabel Intertekstualitas Esai. Tiga kategori dapat dikelompokkan lagi menjadi teks Karya Seni yang terdiri atas seni sastra, seni film, dan musik. Dari jumlah kemunculan setiap kategori teks, dapat dilihat bahwa kategori teks Teori/Konsep, yang terdapat dalam 18 esai, dan teks Karya Seni (disebutkan dalam 17 esai) menjadi kategori teks yang dominan. Perlu diketahui bahwa teks yang menyebutkan nama tokoh juga merujuk pada tokoh sejarah serta tokoh musisi dan perfilman. Sementara itu, nama tokoh juga sering disebut dalam kategori teks Teori/Konsep. Penyebutan nama tokoh ini mempertegas dominasi penyebutan teks yang merujuk pada pemikiran konseptual dan artistik.

Dalam bukunya, Desire in Language: A Semiotic Approach to Language and Art, Julia Kristeva (1980) menyebutkan bahwa teks tidak bersifat individual atau objek 
yang terisolasi, akan tetapi merupakan kompilasi dari tekstualitas budaya. Dalam hal ini, Kristeva mengungkapkan kembali gagasan Mikhail Bakhtin (Raj, 2015) tentang dialog yang melihat korelasi antara penulis, karya, pembaca, masyarakat, dan sejarah. Baik Bakhtin (1984) maupun Kristeva percaya bahwa teks tidak dapat dipisahkan dari teks budaya atau sosial yang lebih besar yang mengonstruksi teks tersebut. Semua teks mengandung struktur ideologis yang diekspresikan melalui wacana. Kristeva menguraikan bahwa teks apa pun dikonstruksikan sebagai mosaik kutipan. Penyebutan berbagai teks dalam antologi Tiada Ojek di Paris pertama-tama dapat dibaca sebagai mosaik kutipan. Pada tahap analisis selanjutnya, keberadaan berbagai teks lain tersebut dapat diinterpretasikan memiliki signifikansi tertentu.

Dua kategori teks yang paling banyak disebutkan dalam antologi berhubungan dengan teks terkait teori/konsep dan teks yang berhubungan dengan seni. Perlu dicatat bahwa teks terkait teori/konsep tidak selalu menyertakan judul buku dari teori atau konsep yang diuraikan, akan tetapi hanya nama penulis dan tahun terbit. Melalui penelusuran berbagai referensi dimaksud, didapat judul-judul buku berikut: Cultural Studies Theory and Practice, Social skills in Interpersonal Communication, The Language of Television, The Metropolis and Mental Life, The Gift, Cultural Theory: The Key Concepts, The Location of Culture, The Crowd, War Crimes in Vietnam, The A B C of Relativity, The Practice of Everyday Life. Sementara itu, teks yang terkait seni dapat dibaca dengan mudah dalam antologi karena menyertakan judul, bahkan beberapa di antaranya menyertakan bait atau teks puisi itu sendiri. Data yang terkumpul dari judul-judul teks sastra adalah sebagai berikut: Mqlam Terang di Jakarta, Bulan Kota Jakarta, Moby Dick, Keadjaiban di Pasar Senen, Dubliners, OrangOrang Bloomington, Nyanyian Lawino, Tetralogi Bumi Manusia, Hoakian di Indonesia, Hikayat Jakarta, Robin Hood Betawi, Betawi: Queen of the East, Satoe Kedjadian jang betoel di Betawi, Bung Karno: Penyambung Lidah Rakyat
Indonesia, Pablawan-Pablawan Belia: Keluarga Indonesia dalam Politik, Petang di Taman.

Dari judul-judul teks dominan yang hadir dalam antologi, dapat dibaca dua hal. Pertama, kajian budaya atau kebudayaan menjadi kata kunci dari teks berupa kutipan atau uraian teoretis-konseptual. Kedua, yang menjadi kata kunci dari referensi teks seni, khususnya seni sastra, adalah Betawi dan Jakarta. Kedua hal ini dapat diartikan sebagai ideologi teks yang menjadi kerangka ideologis dari antologi esai karya SGA, yakni pembacaan tentang kontras antara Betawi yang merepresentasikan situasi tradisional dan Jakarta yang merefleksikan sebuah kota urban. Temuan ini mendukung fakta dari identitas ganda penulis antologi esai yang merupakan seorang sastrawan sekaligus akademisi.

\section{SIMPULAN}

Keseluruhan analisis memperlihatkan bahwa Jakarta sebagai ruang urban menjadi tema utama yang membingkai semua esai dalam Tiada Ojek di Paris. Tema ini sekaligus menjadi wacana dominan yang dapat disimpulkan dari analisis struktur teks. Temuan ini dikembangkan lebih lanjut dalam analisis intertekstualitas. Intertekstualitas dalam penelitian ini dibedakan atas intertekstualitas yang ditemukan dari semua esai dan hubungan intertekstual yang dibangun dari penyebutan teks-teks di luar antologi. Dari analisis intertekstualitas pada bagian pertama, dapat disimpulkan bahwa wacana ruang urban dikemukakan dari perspektif penulis dan memuat pengalaman serta pengamatan yang dilakukannya. Antologi esai digunakan sebagai sarana oleh penulis untuk menyampaikan refleksi dan kritik terkait wacana urban dalam konteks produksi ruang. Temuan penelitian memunculkan realitas Jakarta sebagai ruang urban dengan tiga wacana dominan, yakni identitas kota metropolitan, masalah sosial di jalanan, dan gegar budaya masyarakat Jakarta menghadapi modernitas yang berlangsung cepat dan masif. Sementara itu, analisis intertekstualitas selanjutnya berhubungan dengan berbagai teks yang 
disebutkan dalam antologi. Dapat disimpulkan bahwa muatan sastra dan akademis membingkai antologi esai ini.

Tulisan ini merupakan pembacaan teks dengan terutama membongkar unsurunsur teks yang membangun struktur teks bergenre esai. Temuan yang diperoleh dapat dijadikan dasar dari penelitian selanjutnya dengan korpus yang sama. Penelitian khusus terkait konstruksi identitas Homo Jakartensis juga dapat dilakukan. Selain itu, metode yang sama dapat pula digunakan untuk membedah karya-karya lain Seno Gumira Ajidarma.

\section{DAFTAR RUJUKAN}

Adiprasetio, J. \& Saputra, S. J. (2017). Taman Alun-alun: Produksi Ruang (Sosial) dan Kepublikan. Jurnal Common, 1(2), 118-129.

Ajidarma, S. G. (2015). Tiada Ojek di Paris. Bandung: Penerbit Mizan.

Aminah, S. (2015). Konflik dan Kontestasi Penataan Ruang Kota Surabaya. Masyarakat: Jurnal Sosiologi, 20(1),5979.

Badan Pusat Statistik Provinsi DKI Jakarta. (2018). Jumlah Penduduk Provinsi DKI Jakarta Menurut Kelompok Umur dan Jenis Kelamin, 2018. Diakses dari https://jakarta.bps.go.id/dynamict able/2019/09/16/58/jumlahpenduduk-provinsi-dki-jakartamenurut-kelompok-umur-danjenis-kelamin-2018-.html

Bakhtin, M. (1984). Problems of Dostoevsky's Poetics (Theory and History of Literature, Volume 8). Minneapolis, London: Minnesota University Press.

Candra, N. M. T., Nugroho, W. B., \& Punia, I. N. (2017). Produksi Ruang Sosial melalui Mural di Kota Denpasar. Jurnal Ilmiah Sosiologi (Sorot), 1(1). Skripsi. Denpasar: Universitas Udayana.

Christian, Y \& Desmiwati. (2018). Menuju Urbanisasi Pulau Kecil: Produksi Ruang Abstrak dan Perampasan. Journal of Regional and Rural
Development Planning, 2(1), 45-63. DOI:

http://dx.doi.org/10.29244/jp2wd .2018.2.1.45-63.

Elden, S. (2004). Understanding Henri Lefebure: Theory and the Possible. London-New York: Continuum.

Ensiklopedia Sastra Indonesia. (2019). Seno Gumira Ajidarma (1958 - ...). Diakses dari http:/ / ensiklopedia.kemdikbud.go.i d/sastra/artikel/Seno_Gumira_Aji darma.

Firmansyah, M. J. (Writer), \& Chairunnisa, N. (Editor). (2019, June 16). Tingkat Kemacetan Jakarta Disebut Menurun, Begini Datanya. [Online News]. Jakarta: Tempo.co. Diakses dari

https://metro.tempo.co/read/121

5071/tingkat-kemacetan-jakartadisebut-menurun-begini-datanya.

Fraser, B. (2015). Toward an Urban Cultural Studies: Henri Lefebvre and the Humanities. New York: PALGRAVE MACMILLAN®

Goldmann, L. (1964). Le Structuralisme Génétique en Histoire de la Littérature. MLN, 79(3), 225-239. French Issue (May-1964). Diakses dari

http://www.jstor.org/stable/3042 833.

Goldmann, L. (1980). Essays on Method in the Sociology of Literature. William Q. Boelhower (Penerjemah). St. Louis, Mo: Telos Press.

Kristeva, J. (1980). Desire in Language: $A$ Semiotic Approach to Language and Art. Leon S. Roudiez (Editor). T. Gora et al. (Penerjemah). New York: Columbia University Press.

Lefebvre, H. (1974). La production de l'espace. In L'Homme et la société, N. 31-32. Sociologie de la connaissance marxisme et anthropologie. pp. 15-32. doi : 10.3406/homso.1974.1855.

Diakses dari http://www.persee.fr/doc/homso _0018-

4306_1974_num_31_1_1855. 
Jurnal Pendidikan Bahasa dan Sastra, Volume 20, Nomor 1, April 2020, pp. 16 - 28

Lefebvre, H. (1991). The Production of Space. Donald Nicholson-Smith (Penerjemah). Oxford UK \& Cambridge USA: Basil Blackwel.

Nadolny, A. (2015). Henri Lefebvre's Concept of Urban Space in the Context of Preferences of the Creative Class in a Modern City. Quaestiones Geographicae, 34(2), April2015.

Nurhadi, I., Amiruddin, \& Rozalinna G.M. (2019). "Produksi Ruang dan Perubahan Pengetahuan pada Masyarakat Sekitar Objek Wisata Waterland," Jurnal Kajian Ruang Sosial-Budaya 3(1), 46-64. DOI: 10.21776/ub.sosiologi.jkrsb.2019.0 03.1.04.

Pamungkas, A. S. (2016). Produksi Ruang dan Revolusi Kaum Urban Menurut Henri Lefebvre, Lembar Kebudayaan Indoprogress, LKIP, Edisi 31 (Jan-2016). Diakses dari https://indoprogress.com/2016/0 $1 /$ produksi-ruang-dan-revolusikaum-urban-menurut-henrilefebvre/.

Pasaribu, R. P., Siahaan, U., \& Tobing, R. R. (2018). Re/Produksi Ruang Interaksi Sosial Berbasis Kegiatan Perdagangan dalam Kampung Kota di Sekitar Kampus. Jurnal AGORA, 16(1), pp. 52-59. DOI: http://dx.doi.org/10.25105/agora. v16i1.3211

Probowati, P. N. (2011). Reproduksi Masyarakat dan Implikasi Spasial dalam Proses Transformasi Kampung Laweyan. Tesis. Depok: Universitas Indonesia.
Raj, P. P. E. (2015). Text/Texts: Interrogating Julia Kristeva's Concept of Intertextuality. Ars Artium: An International Peer Reviewed-cum-Refereed Research Journal of Humanities and Social Sciences, 3, 77-80 (Jan-2015).

Schmid, C. (2008). Henri Lefebvre's Theory of the Production of Space: Towards a three-dimensional dialectic. In Goonewardena, K., Kipfer, S., Milgrom, R., \& Schmid, C. (Eds.), Space, Difference, Everyday Life: Reading Henri Lefebure (pp. 2745). New York: Routledge.

Setiawan, A. (2017). Produksi Ruang Sosial Sebagai Konsep Pengembangan Ruang Perkotaan (Kajian atas Teori Ruang Henry Lefebvre). Haluan Sastra Budaya, Jurnal Ilmiah Ilmu-ilmu Humaniora. DOI: 10.20961/hsb.v33i1.4244.

Sudaryono. (2008). Perencanaan Kota Berbasis Kontradiksi: Relevansi Pemikiran Henri Lefebvre dalam Produksi Ruang Perkotaan Saat ini. Jurnal Perencanaan Wilayah dan Kota, 19(1), 1-12.

Wulandari, S. (2017). Produksi Ruang dan Representasi Ruang dalam Dinamika Konflik Spasial di Kampung Inggris. Tesis. Surabaya: Universitas Airlangga.

Yudhistira, A. W. (Editor). (2019, June 22). Tingkat Kemacetan di Jakarta Berkurang. [Online News]. Jakarta: Katadata.co.id. Diakses dari https://katadata.co.id/infografik/2 019/06/22/tingkat-kemacetan-dijakarta-berkurang. 